Original Research Paper

\title{
Serum Adenosine Deaminase Level in Iraqi Women with Toxoplasmosis with a History of Abortion
}

\author{
${ }^{1}$ Ahmed H. AL-Khafaji, ${ }^{2}$ Tarik I. AL-Jeboori and ${ }^{3}$ Ameena S.M. Juma \\ ${ }^{I}$ Pathological Analysis Department, College of Science, Thi-Qar University, Nasseriyah, Iraq \\ ${ }^{2}$ Microbiology Department, College of Medicine, Al-Nahrain University, P.O. Box 14222, Baghdad, Iraq \\ ${ }^{3}$ Head of Biology Department, Cihan University, Erbil, Kurdistan Region of Iraq
}

Article history

Received: 14-03-2015

Revised: 19-06-2015

Accepted: 30-12-2015

Corresponding Author: Ameena S.M. Juma

Department of Biology, Cihan

University, Erbil, Kurdistan

Region of Iraq

Email: ameena_juma@yahoo.com

\begin{abstract}
Sixty women who had abortion were selected for this study. Serum was collected from the women. ELISA test was used to detect antiToxoplasma specific antibodies. Those women were divided into three groups according to the presence or absence of specific anti-Toxoplasma antibodies. These groups included the women with $\operatorname{IgG}(18)$, the women with $\operatorname{IgM}(14)$ and the women with both $\operatorname{IgG}$ and IgM (12). The other 16 women had no antibodies against Toxoplasma. Twenty-four healthylooking women had been selected as controls. Serum was collected from those women and tested for anti-Toxoplasma antibodies. Those that revealed any antibody titer against Toxoplasma were excluded from the study. The activity of ADA was determined in the serum according to the method of Giusti. The mean concentration of ADA in the women who had anti-Toxoplasma IgM antibody was significantly higher $(\mathrm{P}<0.0001)$ than that of healthy controls and the women who had $\operatorname{IgG}$, while there was no significant differences between women who had IgG antibody and healthy controls $(\mathrm{P}>0.05)$. Since a relationship exists between ADA activity and the cell mediated immune response, this result confirms the fact that Toxoplasma antigen induces T-lymphocytes proliferation.
\end{abstract}

Keywords: Toxoplasmosis, Abortion, Adenosine Deaminase

\section{Introduction}

Adenosine deaminase, ADA, (adenosine aminohydrolase, EC 3.5.4.4), is the enzyme that irreversibly catalyzes the hydrolytic deamination of adenosine and deoxyadenosine to inosine and deoxyinosine respectively. The activity of this enzyme defined as the amount of enzyme that deaminates one micromole of substrate per minute, under specified steady assay conditions. The normal values of ADA in serum range from 2-17 U/L (Akalal et al., 2004). This enzyme is widely distributed in animal tissues. It showed that normal blood of humans and mammals contained activity. The highest activity was found in the cecum, intestinal mucosa and spleen, while less or no activity was found in skeletal muscles, skin and bone. This enzyme is present in the cytoplasmic fraction of the cell and a certain amount is located in the nucleus (Smillie, 1957).
Studies have suggested a critical role for ADA activity in the normal development of the immune system (Thompson and Seegmiller, 1980). The conversion of adenosine and deoxyadenosine into their respective inosine nucleosides is an initial step of a series of reactions responsible for lymphocytes proliferation and differentiation. Therefore, ADA considered an indicator of cellular immunity and fundamental for the differentiation of lymphocytes. In humans, the lack of this enzyme results in severe lymphopenia and immunodeficiency, bringing the risk of an early death for the affected individuals (Blackburn and Kellems, 2005; Bollinger et al., 1996).

Toxoplasmosis, caused by the protozoan parasite Toxoplasma gondii, ranks third in the United States for deaths caused by food-born pathogens (Hughes et al., 2000). Toxoplasmosis can be transmitted across the placenta in women who have the infection, acquired 
either for the first time or recurring (especially in persons who are immunocompromised) during pregnancy and it is developing asymptomatic and when passed in pregnancy period, it can cause abortion, dead birth and births with congenital anomalies according to the strain of the parasite, virulence factors and maternal immuneresponsivness (Rorman et al., 2006). T. gondii is an important wateror food-born pathogen that is capable of causing severe disease in infants from infected mothers and in the immunocompromised patients (Roberts and McLeod, 1999). It is generally assumed that approximately 25 to $30 \%$ of the world's human population is infected by Toxoplasma (Montoya and Liesenfeld, 2004). Actually, the prevalences vary widely between countries (from 10 to $80 \%$ ) and often within a given country or between different communities in the same region (Pappas et al., 2009). Low seroprevalences (10 to 30\%) have been observed in North America, in South East Asia, in Northern Europe and in Sahelian countries of Africa. Moderate prevalences ( 30 to $50 \%$ ) have been found in countries of Central and Southern Europe and high prevalences have been found Latin America and in tropical African countries. In Arab countries, toxoplasmosis had been investigated such as in United Arab Emirates (Mohammed and Al-Nasiry, 1996), Saudi Arabia (AlQurashi et al., 2001) and in Egypt (Soliman et al., 2001). In Iraq, many studies were published about the seroprevalence of toxoplasmosis by using different techniques like IHA, IFAT and ELISA (Kubba et al., 1986; Niazi et al., 1992).

\section{Materials and Methods}

\section{Subject Selection}

\section{Patients}

Sixty women who had abortion were selected for this study. They were referred to the Central Health Laboratory in Baghdad according to the physician's reports, indicating the possibility of them having toxoplasmosis. Serum and venous heparinized blood was collected from those women in a period between January 2003 and March 2003.

\section{Controls}

Twenty-four healthy-looking women had been selected as controls to compare with our patients in the same parameters of this study. Serum and venous heprinized blood was collected from those women and tested for anti-Toxoplasma antibodies. Those that revealed any antibody titer against Toxoplasma were excluded from the study.

\section{Enzyme Linked Immunosorbant Assay (ELISA)}

The type of ELISA in this study was direct ELISA principled as the antigen of Toxoplasma gondii was absorbed on the ELISA plate to detect specific IgM or IgG antibody in the patient's sera when added to the well of the plate, then anti-human conjugated antibody and substrate added to get the color reaction.

This test performed by the use of ELISA kits from Omega Diagnostics Company, Scotland to detect of $\mathrm{IgG}$ and IgM antibodies against Toxoplasma gondii in the patient's sera. The patient's sera were stored for several days at $-20^{\circ} \mathrm{C}$ until the test performed.

All preparations and assay procedure applied according to the kit manufacturer's manual.

Note: All analysis of this study were accomplished in 2003 but the writing of the manuscript was performed in 2015 because critical conditions of the editors.

\section{Calculation and Interpretation of Results:}

The average Optical Density (OD) of the low positive control was calculated and this was the Cut-Off value of the assay. The sample OD was divided by the Cut-Off value obtained above. A ratio greater than 1:1 indicated a positive result; a ratio lower than 0.9 indicated a negative result. A ratio between 0.9 and 1.1 indicated an equivocal result. An equivocal sample must be retest with a fresh new sample. In the case that the same equivocal result was obtained, the test must be repeated with a new sample after 2-4 weeks.

\section{Adenosine Deaminase Activity Assay}

The activity was determined in the serum according to the method of Giusti (Akalal et al., 2004).

\section{Reagents:}

All reagents were prepared at the time of assay initiation to avoid any loss or gain of ammonia in any of the reagents, which may interfere with the results.

\section{Phosphate Buffer (50 mM)}

About $4.73 \mathrm{gm}$ of hydrated sodium dihydrogen phosphate $\left(\mathrm{NaH}_{2} \mathrm{PO}_{4} \cdot \mathrm{H}_{2} \mathrm{O}\right)$ (Riedel-de-Haen) and 5.62 gm of hydrated disodium hydrogen phosphate $\left(\mathrm{Na}_{2} \mathrm{HPO}_{4} \cdot 12 \mathrm{H}_{2} \mathrm{O}\right)$ (Riedel-de-Haen) were dissolved in DDW, bringing the final volume to $100 \mathrm{ml}$ and adjusting the $\mathrm{pH}$ to 6.5 with phosphoric acid $\left(\mathrm{H}_{3} \mathrm{PO}_{4}\right)$ (Fluka). 


\section{Buffered Adenosine Solution (21 mM Adenosine, 50 mM Phosphate)}

About $15 \mathrm{ml}$ of phosphate buffer was added to $140 \mathrm{mg}$ of adenosine $\left(\mathrm{C}_{10} \mathrm{H}_{23} \mathrm{~N}_{5} \mathrm{O}_{4}\right)(\mathrm{BDH})$ and warmed in a $70^{\circ} \mathrm{C}$ water bath for 10 min then cooled under running water. The $\mathrm{pH}$ was adjusted to 6.5 with phosphoric acid and the volume was brought to $25 \mathrm{ml}$ with phosphate buffer.

\section{Ammonium Sulphate Stock Solution (15 mM)}

About $1.982 \mathrm{gm}$ of anhydrous ammonium sulphate $\left[\mathrm{NH}_{4}\right]_{2} \mathrm{SO}_{4}$ (Fluka) were dissolved in DDW bringing the finals volume to $1000 \mathrm{ml}$.

Ammonium Sulphate Standard Solution (75 $\mu M$; $0.15 \mu \mathrm{vol}, \mathrm{NH} 3 / \mathrm{ml}$ )

About $0.5 \mathrm{ml}$ of ammonium sulphate stock solution was diluted to $100 \mathrm{ml}$ with phosphate buffer.

Phenol/Nitroprusside Solution (106 mM Phenol; 0.17mM Sodium Nitroprusside)

About 10 gm of phenol $\left(\mathrm{C}_{6} \mathrm{H}_{5} \mathrm{OH}\right)(\mathrm{DH})$ and $50 \mathrm{gm}$ of sodium nitroprusside $\left(\mathrm{Na}_{3}\left[\mathrm{Fe}(\mathrm{CN})_{5} \mathrm{NO}\right] .2 \mathrm{H}_{2} \mathrm{O}\right)$ $(\mathrm{BDH})$ were dissolved in DDW bringing the final volume to $1000 \mathrm{ml}$.

\section{N Sodium Hydroxide}

About 40 gm of sodium hydroxide $(\mathrm{NaOH})(\mathrm{BDH})$ was dissolved in DDW bringing the final volume to $1000 \mathrm{ml}$.

\section{Alkaline Hypochlorite Solution (11mM NaOCl; 125 $m \mathrm{MNaOH}$ )}

About $125 \mathrm{ml}$ of $1 \mathrm{~N}$ sodium hydroxide solution and $16.4 \mathrm{ml}$ of sodium hypochlorite $(\mathrm{NaOCl}-5 \% \quad \mathrm{w} / \mathrm{v})$ (Fluka) were mixed with DDW bringing the final volume to $1000 \mathrm{ml}$.

\section{Assay Procedure}

An adenosine blank (for the whole series) was prepared and a corresponding number of sample blanks (one for each sample, without adenosine) were also prepared according to Table 1, the sample being the serum. The calculations were made as follows:

$$
\begin{aligned}
& \mathrm{E}_{\text {sample }}-\mathrm{E}_{\text {sample blank }} \mathrm{A} \\
& \mathrm{E}_{\text {adenosine blank }-} \mathrm{E}_{\text {reagent blank }} \mathrm{B} \\
& \mathrm{E}_{\text {standard }-} \mathrm{E}_{\text {reagent blank }=} \mathrm{C}
\end{aligned}
$$

Enzyme activity $=((\mathrm{A}-\mathrm{B}) / \mathrm{C}) \times 50(\mathrm{U} / \mathrm{L}) ; 37^{\circ} \mathrm{C}$

The contents were mixed, tubes stoppered and incubated for $60 \mathrm{~min}$ in a water bath at $37^{\circ} \mathrm{C}$.

Then the following solutions were added.

The last two solutions were added for coloring and the contents of the tubes mixed before pipetting into the next tube. The tubes were incubated for $30 \mathrm{~min}$ in a water bath at $37^{\circ} \mathrm{C}$. The Absorbency (A) of the sample was read using a spectrophotometer at $628 \mathrm{~nm}$ against DDW.

\section{Statistical Analysis}

The data were statistically analyzed using student's Ttest according to Snedecor and Cochran (Hovi et al., 1979) by using Excel 2003 software.

\section{Ethical Approval}

This research underwent to the terms of ethical considerations and in accordance with the form prepared for this purpose by the Iraqi Ministry of Health also got the approval of the research by the Committee of ethical standards in the Faculty of Medicine, Al-Nahrain University, one of the colleges affiliated to the Ministry of Higher Education and

\begin{tabular}{|c|c|c|c|c|c|}
\hline \multirow[b]{2}{*}{ Reagents } & \multicolumn{5}{|l|}{ Tubes } \\
\hline & Reagent blank (ml) & Standard (ml) & Adenosine blank (ml) & Sample blank (ml) & Sample (ml) \\
\hline -Phosphate buffer & 1.0 & - & - & 1.0 & - \\
\hline -Buffered adenosine solution & - & - & 1.0 & - & 1.0 \\
\hline $\begin{array}{l}\text {-Ammonium sulphate } \\
\text { (standard solution) }\end{array}$ & - & 1.0 & - & - & - \\
\hline -Sample (serum) & - & - & - & 0.05 & 0.05 \\
\hline -DDW & 0.05 & 0.05 & 0.05 & - & - \\
\hline Phenol nitroprusside solution & 3.0 & 3.0 & 3.0 & 3.0 & 3.0 \\
\hline Alkaline hypochlorite solution & 3.0 & 3.0 & 3.0 & 3.0 & 3.0 \\
\hline
\end{tabular}
Scientific Research, Iraq.

Table 1. Experimental design for ADA estimation in the serum of women infected with $T$. gondii 


\section{Results}

\section{ELISA Results}

Sixty samples of women's serum had been tested for specific IgG and IgM antibodies to confirm the presence of toxoplasmosis in those women by using ELISA kit (Omega diagnostics).

The results showed that 44 of 60 women $(73.3 \%)$ (Table 2) have antibodies against Toxoplasma, 18 $(56.2 \%)$ (Table 3) of which have IgG antibody, 14 (43.7\%) (Table 4) have IgM and 12 (27.2\%) (Table 5) have both $\mathrm{IgG}$ and IgM. The other 16 of 60 women, although they had abortion (single or repeated), they were negative for toxoplasmosis using ELISA.

On the other hand, samples from 24 healthy looking women were collected as controls and tested for IgG and IgM specific antibodies for Toxoplasma by using ELISA kit. The results indicated that 20 women were negative to $\mathrm{IgG}$ and IgM of Toxoplasma, while the remaining 4 women had Toxoplasma antibodies.

The sensitivity and specificity of the ELISA kit had been calculated and present as $91.6 \%$ sensitivity and $55.5 \%$ specificity.

Table 2. Frequency distribution of Toxoplasma gondii antibody using ELISA in seropositive women with history of abortion compared with healthy controls

\begin{tabular}{llll}
\hline & $\begin{array}{l}\text { ELISA } \\
\text { positive }(\%)\end{array}$ & $\begin{array}{l}\text { ELISA } \\
\text { negative }(\%)\end{array}$ & $\begin{array}{l}\text { Total } \\
(\%)\end{array}$ \\
\hline Abortion & $44(73.3)$ & $16(26.6)$ & $60(100)$ \\
No abortion (controls) & $4(16.6)$ & $20(83.3)$ & $24(100)$ \\
Total & $48(57.1)$ & $36(24.8)$ & $84(100)$ \\
\hline
\end{tabular}

Table 3. Frequency distribution of Toxoplasma gondii IgG antibody using ELISA test in seropositive women with a history of abortion compared with healthy controls

\begin{tabular}{llll}
\hline & $\begin{array}{l}\text { IgG } \\
\text { positive (\%) }\end{array}$ & $\begin{array}{l}\text { IgG } \\
\text { negative (\%) }\end{array}$ & $\begin{array}{l}\text { Total } \\
(\%)\end{array}$ \\
\hline Single or repeated abortion & $18(56.2)$ & $14(43.7)$ & $32(100)$ \\
No abortion (controls) & $2(9)$ & $20(90.9)$ & $22(100)$ \\
Total & $20(37)$ & $34(62.9)$ & $54(100)$ \\
\hline
\end{tabular}

Table 4. Frequency distribution of Toxoplasma gondii IgM antibody using ELISA test in seropositive women with a history of abortion compared with healthy controls

\begin{tabular}{llll}
\hline Type of cases & $\begin{array}{l}\text { IgM } \\
\text { positive (\%) }\end{array}$ & $\begin{array}{l}\text { IgM } \\
\text { negative (\%) }\end{array}$ & $\begin{array}{l}\text { Total } \\
(\%)\end{array}$ \\
\hline Single or repeated abortion & $14(43.7)$ & $18(56.2)$ & $32(100)$ \\
No abortion (controls) & $2(9)$ & $20(90.9)$ & $22(100)$ \\
Total & $16(29.6)$ & $38(70.3)$ & $54(100)$ \\
\hline
\end{tabular}

Table 5. Frequency distribution of Toxoplasma gondii $\operatorname{IgG}$ and IgM antibodies using ELISA test in seropositive women with a history of abortion compared with healthy controls

\begin{tabular}{llll}
\hline & $\begin{array}{l}\text { IgG\&IgM } \\
\text { positive }(\%)\end{array}$ & $\begin{array}{l}\text { IgG\&IgM } \\
\text { negative }(\%)\end{array}$ & $\begin{array}{l}\text { Total } \\
(\%)\end{array}$ \\
\hline Sype of cases & $12(27.2)$ & $32(72.7)$ & $44(100)$ \\
No abortion (controls) & $0(0)$ & $24(100)$ & $24(100)$ \\
Total & $12(17.6)$ & $56(82.3)$ & $68(100)$ \\
\hline
\end{tabular}

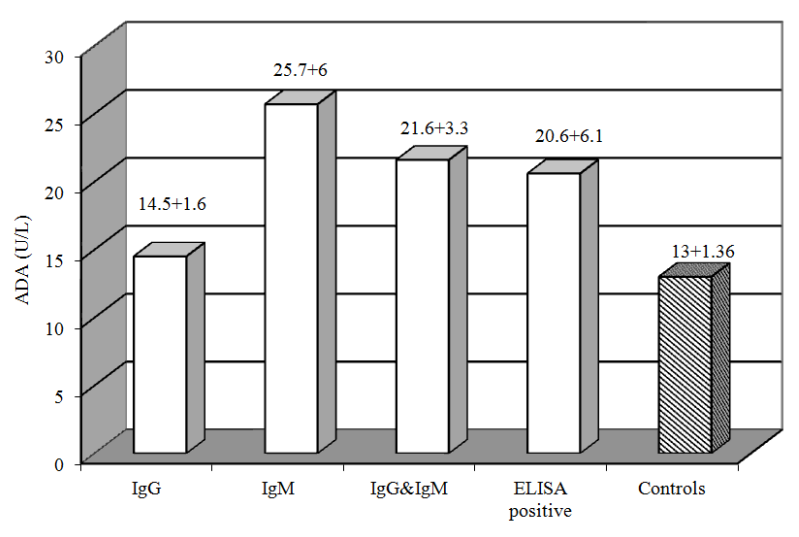

Fig. 1. The mean of Adenosine Deaminase Activity (ADA) in the sera of seropositive women for toxoplasmosis compared with healthy controls

\section{Adenosine Deaminase Activity Result}

The mean concentration of ADA in the women who had anti-Toxoplasma IgM antibody was significantly higher $(\mathrm{P}<0.0001)$ than that of healthy controls and the women who had $\mathrm{IgG}$, while there was no significant differences between women who had $\operatorname{IgG}$ antibody and healthy controls $(\mathrm{P}>0.05)$. Figure 1 reveals the mean of ADA level in the women according to the presence and absence of anti-Toxoplasma specific antibodies.

\section{Discussion}

Since a relationship exists between ADA activity and the cell mediated immune response and because there is no data about ADA activity in toxoplasmosis, it was aimed to determine serum ADA activity of patients with toxoplasmosis and compare the results with the control group. ADA is found in most cells, but its chief role concerns the proliferation and differentiation of lymphocytes especially $\mathrm{T}$ lymphocytes (Ozcan et al., 1998).

This study shows increasing levels of ADA in women that had anti-Toxoplasma IgM antibody. This result confirms the fact that Toxoplasma antigen induces T-lymphocytes proliferation. However, the enzyme activity increases substantially during mitogenic (Galanti et al., 1981) and an antigenic response of lymphocytes and conversely, lymphocyte blastogenesis is inhibited by inhibitors of ADA (Piras et al., 1982). As a marker of cellular immunity, its plasma activity is found to be elevated in those diseases in which there is a cell-mediated immunity (Sullivan et al., 1977; Van der Weyden and Kelley, 1977).

ADA is an enzyme capable of catalyzing purine bases and whose principal biologic activity is detected in T lymphocytes (Hirschhorn, 1990). The role of this enzyme in cellular immune function was highlighted 
following the discovery of reduced levels in patients with severe combined immune deficiency (Shubber et al., 1999). Patients with a low level of ADA activity have a later onset of clinical disease owing to a slower and sometimes less complete loss of immune function (Juma et al., 2003).

Similar results of decreased ADA activity in parasitic diseases were observed in schistosomiasis in humans (Juma et al., 2003) and fascioliasis gigantica in sheep (Shubber et al., 1999) and in mice experimentally infected with Echinococcus granulosus (Al-Ubaidi et al., 2003). The reduction of ADA level could be related to the state of immune unresponsiveness associated with hydatid disease in humans (Al-Ubaidi et al., 2003).

Another study related with current study showed decreased in ADA level in patients with antiToxolasma IgG antibody when compared with control group and same results obtained in patients with Giardiasis (Karaman et al., 2009). All these studies revealed that ADA is actually related to the proliferative activity and the differentiation of the lymphocytes (Galanti et al., 1981).

\section{Conclusion}

Toxoplasmosis responsible for abortion in infected pregnant women and there must be an evidence sustains the immune tests used in the diagnosis of toxoplasmosis. This study opens up new prospects for use of ADA as an indicator for toxoplasmosis infection.

\section{Acknowledgement}

I grateful acknowledge the support of the team workers in the Microbiology Department in the College of Medicine of Al-Nahrain University.

\section{Funding Information}

The authors have no support or funding to report.

\section{Author's Contributions}

Ahmed H. AL-Khafajy: Preparation, techniques and publication.

Tarik I. AL-Jeboori: Design the plane.

Ameena S.M. Juma: Design the proposal.

\section{Ethical}

This research underwent to the terms of ethical considerations and in accordance with the form prepared for this purpose by the Iraqi Ministry of Health also got the approval of the research by the Committee of ethical standards in the Faculty of Medicine, Al-Nahrain University, one of the colleges affiliated to the Ministry of Higher Education and Scientific Research, Iraq.

\section{References}

Akalal, D.B.G., C.H. Schein and G.T. Nagle, 2004. Mollusk-derived growth factor and the new subfamily of adenosine deaminase-related growth factors. Curr. Pharmaceut. Des., 10: 3893-3900. DOI: $10.2174 / 1381612043382594$

Al-Qurashi, A.R., A.M. Ghandour, O.E. Obeid, A.A. AlMulhim and S.M. Makki, 2001. Seroepidemiological study of Toxoplasma gondii infection in the human population in the eastern region. Saudi Med. J., 22: 13-18.

Al-Ubaidi, A.H.M., T.I. Al-Jeboori and A.S.M. Juma, 2003. Serum adenosine deaminase level in patients with hydatid disease (Echinococcus granulosus). Iraqi J. Med. Sci., 2: 25-28.

Blackburn, M.R. and R.E. Kellems, 2005. Adenosine deaminase deficiency: Metabolic basis of immune deficiency and pulmonary inflammation. Advanc. Immunol., 86: 1-41.

DOI: $10.1016 / \mathrm{S} 0065-2776(04) 86001-2$

Bollinger, M.E., F.X. Arredondo-Vega, I. Santisteban, K. Schwarz and M.S. Hershfield et al., 1996. Hepatic dysfunction as a complication of adenosine deaminase deficiency. N. Engl. J. Med., 334: 1367-1371. DOI: 10.1056/NEJM199605233342104

Galanti, B., S. Nardiello, M. Russo and F. Fiorentino, 1981. Increased lymphocyte adenosine deaminase in typhoid fever. Scand. J. Inf. Dis., 13: 47-50.

Hirschhorn, R., 1990. Adenosine deaminase deficiency. Immunodefic. Rev., 2: 175-198.

Hovi, T., J.F. Smyth, A.C. Allison and S.C., Williams, 1979. Role of adenosine deaminase in lymphocyte proliferation. Clin. Exp. Immunol., 23: 395-403.

Hughes, J.M., D.G. Colley, A. Lopez, V.J. Dietz and M. Wilson et al., 2000. Preventing congenital toxoplasmosis Morbidity Mortality Weekly Report, 49: 57-75.

Juma, A.S.M., T.I. Al-Jeboori, M.S. Tawfiq and R.A. Fadhil, 2003. Adenosine deaminase activity in the serum of patients with Schistosoma haematobium and those with bladder carcinoma. Iraq J. Med. Sci., 2: $24-28$.

Karaman, U., L. Beytur, T.R. Kiran and C. Colak, 2009. Adenosine deaminase level in the serum of the patients Toxoplasma gondii seropositive and Giardia intestinalis. Afr. J. Microbiol. Res., 3: 654-657.

Kubba, K., L.D. Al-Tahi, A. Al-Obiedi and H.S. Tawfiq, 1986. A study of toxoplasmosis in pregnancy in Iraq. Iraq Med. J., 34: 9-14.

Mohammed, N.R.S. and S.G. Al-Nasiry, 1996. Toxoplasmosis among Iraqi women with history of abortion: Serological study. J. Comm. Med.

Montoya, J.G. and O. Liesenfeld, 2004. Toxoplasmosis. Lancet, 363: 1965-1976.

DOI: $10.1016 / \mathrm{S} 0140-6736(04) 16412-\mathrm{X}$ 
Niazi, A.D., W.M. Nsaif, S.A. Abbas and S.F. Gzar, 1992. Prevalance of Toxoplasma antibodies in Iraqi population. J. Fac. Med. Baghdad, 34: 23-30.

Ozcan, E., K. Abdurrahim, S.G. Mehmet, B. Vedat and S. Adnan et al., 1998. Adenosine deaminase activities in sera, lymphocytes and granulocytes in patients with cutaneous Leishmaniasis. Mem. Inst. Oswalolo-Cruz, 93: 491-494.

DOI: $10.1590 / \mathrm{S} 0074-02761998000400014$

Pappas, G., N. Roussos and M.E. Falagas, 2009. Toxoplasmosis snapshots: Global status of Toxoplasma gondii seroprevalence and implications for pregnancy and congenital toxoplasmosis. Int. J. Parasitol., 39: 1385-1394.

DOI: 10.1016/j.ijpara.2009.04.003

Piras, M.A., C. Gakis, M. Budroni and G. Andreoni, 1982. Immunological studies in Mediterranean spotted fever. Lancet, 319: 1249-1249. DOI: $10.1016 / \mathrm{S} 0140-6736(82) 92375-3$

Roberts, F. and R. McLeod, 1999. Pathogenesis of toxoplasmic retinochoroiditis. Trends Parasitol., 15: 51-57. DOI: 10.1016/S0169-4758(98)01377-5

Rorman, E., C.S. Zamir, I. Rilkis and H.B. David, 2006. Congenital toxoplasmosis-prenatal aspects of Toxoplasma gondii infection. Reprod. Toxicol., 21: 458-472. DOI: 10.1016/j.reprotox.2005.10.006
Shubber, E.K., A.H. Khaled and B.M.A. Al-Allak, 1999. ADA activity of blood cells and lymphocyte proliferation from sheep experimentally infected with Fasciola gigantica. Iraqi J. Biol. Sci., 18: 1-11

Smillie, R.M., 1957. The breakdown of the adenosine phosphates by brain tissue. Arch Biochem. Biophys., 67: 213-224. DOI: 10.1016/0003-9861(57)90259-X

Soliman, M., M.S. Nour-Eldin, H.M. EI-Naggar, M.E. El-Ghareb and N.I. Ramadan, 2001. Toxoplasma antibodies in normal and complicated pregnancy. $\mathrm{J}$. Egy. Soci. Parasitol., 31: 637-646.

Sullivan, J.L., W.R.A. Osborne and R.J. Wedgwood, 1977. Adenosine deaminase activity in lymphocytes. Br. J. Haematol., 37: 157-158. DOI: $10.1111 / \mathrm{j} .1365-2141.1977 . t b 08825 . \mathrm{x}$

Thompson, L.F. and J.E. Seegmiller, 1980. Adenosine deaminase deficiency and severe combined immunodeficiency disease. Adv. Enzymol. Related Areas Molecular Biol., DOI: $10.1002 / 9780470122969 . c h 4$

Van der Weyden, M.B. and W.N. Kelley, 1977. Adenosine deaminase deficiency and severe combined immunodeficiency. Life Sci., 20: 1645-1650. DOI: $10.1016 / 0024-3205(77) 90337-X$ 